\title{
COMPARATIVE STUDY BETWEEN CELERY LEAVES AND BROCCOLI FLOWERS FOR THEIR CHEMICAL COMPOSITION AND AMINO ACIDS AS WELL AS PHENOLIC AND FLAVONOID COMPOUNDS
}

\author{
Y.A.M. Ashoush ${ }^{(1)}$, A.M.F. Ali ${ }^{(1)}$, M.M. Abozid ${ }^{(1)}$ and M.S.M. Salama ${ }^{(2)}$ \\ (1) Agriculture biochemistry department, Faculty of Agriculture, Menoufia University \\ (2) Mashtoul Elsouk Hospital Sharqia Governorate
}

Received: Dec. 4,2016

Accepted: Dec. 19,2016

\begin{abstract}
The objective of such research was to study the chemical composition as well as phenolic and flavonoid compounds in dried celery leaves and broccoli flowers. Celery leaves contained moisture $88.72 \%$ fresh weight but in dried weight total carbohydrates, crude protein, total lipids, crude fiber and total ash contents were $36.8 \%, 19.47 \%, 2.1 \%, 19.85 \%$ and $20.98 \%$ respectively. While broccoli flowers contained moisture $89.43 \%$ fresh weight but in dried weight total carbohydrates $44.8 \%$, crude protein $24.79 \%$, total lipids $5.8 \%$, crude fiber $15.29 \%$ and total ash contents were $44.8 \%, 24.79 \%, 5.8 \%, 15.29 \%$ and $7.67 \%$ respectively. Celery leaves contained 17 amino acids among them aspartic acid, glutamic acid, valine, alanine, leucine and phenylalanine were the major ones comparing with 17 amino acids in broccoli flowers which were glutamic acid, aspartic acid, alanine, arginine, valine and leucine in high amounts. Total phenolic and flavonoid compounds in celery leaves were 30.3 and $18.5 \mathrm{mg} / \mathrm{g}$ comparing with 38.4 and $22.5 \mathrm{mg} / \mathrm{g}$ of them in broccoli flowers respectively. HPLC results showed that celery leaves contained 22 of phenolic compounds, among them as well as pyrogallol , E.vanillic, ellagic, benzoic, chlorogenic, ferulic and $\mathrm{P}$-OH-benzoic acids were the major active constituents comparing with 23 of phenolic compounds in broccoli flowers which contained as well as pyrogallol those benzoic, $\mathrm{P}$-OH-benzoic, salycilic, E-vanillic and chlorogenic acids were the major of phenolic compounds. Celery leaves contained 17 of flavonoids the highest amounts of them were rosmarinic, luteolin, hesperidin and apig.6-rhamnose 8-glucose comparing with 21 of flavonoids in broccoli flowers which accounted the highest values for luteo.6-arbinose 8glucose, hesperidin and rosmarinic acid. Phenolic and flavonoid compounds were detected and determined by HPLC.
\end{abstract}

Key words: Celery - Broccoli - Amino acids - phenolics - Flavonoids - Reducing power.

\section{INTRODUCTION}

Celery (Apium graveolens) is a herbal member of the family Apiaceae. It is grown as leafy vegetable crop and medicinal herb. In Egypt, celery is cultivated in two seasons "winter and summer". Celery cultivates as a vegetable crop for the thick, succulent, green and blanched leaf stalks which are esteemed as salad and to a lesser extent as a cooked vegetable. Celery pungent fruits are used in salads, soups, vegetable dishes, meat dishes, celery salt and fruits (Halim et al., 1990) .

Medicinal plants provide an important sources of raw materials for pharmaceutical, cosmetic and food industries. Celery has been considered as a medicinal plant since it has been used as an aphrodisiac, anthelmintic, antispasmodic, carminative, diuretic, against asthma bronchitis and swollen glands as well as it provides temporary relief from rheumatism and lumbago. It used also as laxative, sedative, stimulant, and tonic and contains many of chemical compounds such as phenolics, flavonoids and vitamins such as vitamin $C$ and $B$ complex as well as mineral elements (Antuono et al. ,2002). 
Broccoli (Brassica oleracea L. var. Italica) is a member of the Brassicaceae family as a wild form of this family. Broccoli is an Italian vegetable native to the Mediterranean region (Abou El-Magd et al., 2006). Broccoli is an important vegetable crop and has high nutritional and good commercial value. Broccoli is becoming increasingly popular as fresh vegetable and as a significant source of nutritional antioxidants, such as vitamins and carotenoids, as well as biologically active dietary components, such as, flavonoids, hydrocinnamic acid, and sulphur containing compounds, such as the glucosinolates (Price et al., 1998). Broccoli also is considered as a significant source of sulforaphane glucosinolates, a phytochemical compond that is believed to have strong anticarcinogenic properties. Broccoli contains other compounds exhibiting anti-cancer effects, that is protocatechuic acid, chlorogenic acid and carotenoids (Yoldas et al., 2008).

The aim of the present studies was to investigate the chemical composition and amino acids as well as phenolic and flavonoid compounds as a comparative study.

\section{MATERIALS AND METHODS 1- Plant collection and identification.}

Fresh leaves of celery plants (Apium graveolens L.) and broccoli flowers (Brassica olearacea L.) were obtained from the Agriculture Research Center in Giza, Egypt, in winter, (February 2015). The plants were identified in Horticulture Department, Faculty of Agriculture, Minoufia University. Plant samples were washed and air-dried for 24 hours, then dried at $50{ }^{\circ} \mathrm{C}$. The dried samples were grinded into fine powder and kept in refrigerator for analysis.

\section{2- Determination of chemical composition. content :-}

Plant samples were oven dried at $105^{\circ} \mathrm{C}$ for $24 \mathrm{~h}$ by using electrical oven. The samples were weighed before and after drying and the moisture content was calculated, according to AOAC, (2000).

\section{2-2: Determination of ash:-}

Ash content was determined by ashing sample at $550^{\circ} \mathrm{C}$ for 6 hours according to AOAC, (2000).

\section{2-3: Determination of crude fiber:-}

Crude fiber was determined according to AOAC, (2000), that $2.0 \mathrm{~g}$ of sample was placed in a round bottom flask, $50 \mathrm{ml}$ of $0.255 \mathrm{~N} \mathrm{H}_{2} \mathrm{SO}_{4}$ was added and the mixture was boiled under reflux for 30 minutes. The hot solution was filtered under suction. The insoluble matter was washed several times with hot water until samples were acid free. Thereafter, samples were transferred into a flask containing $50 \mathrm{ml}$ of hot $0.313 \mathrm{~N} \mathrm{NaOH}$ solution. The insoluble residues were washed with hot water until base free, then dried to a constant weights at $100^{\circ} \mathrm{C}$ and were cooled in a desiccator and weighed (X1). The weighed samples were incinerated in a muffle furnace at $525^{\circ} \mathrm{C}$ for two hours, cooled in a desiccator and re-weighed (X2). The crude fibre was calculated as follows equation :

Crude fiber $(\%)=\frac{[X 1-X 2] \times 100}{\text { Weight of sample }}$

Where $\mathrm{X} 1-\mathrm{X} 2$ = the loss in weight by ashing.

\section{2-4: Determination of total carbohydrate:-}

A known weight $(0.2 \mathrm{gm}$.) of dried samples were completely hydrolyzed for 6 hours with $\mathrm{HCl}(1 \mathrm{~N})$ on boiling water bath under reflux condenser. The solutions were then filtered and the filtrates were clarified by the leading and deleading method using lead acetate solution (137 gm / L) and the excesses of lead salts was precipitated using N/3 disodium hydrogen phosphate solution. The extracts were transferred into a measuring flasks $(50 \mathrm{ml}$.). The combined 
filtrates were completed to the mark with distilled water.

The sugars were determined according to the method of Dubois et al, (1956) as follows:

An aliquot of (1 $\mathrm{ml}$.) of the sugars solution was quantitatively transferred into a test tube and treated with $1 \mathrm{ml} .5 \%$ aqueous phenol solution followed by $5 \mathrm{ml}$. of concentrated sulphuric acid added by a fast delivery pipette. The blank experiment was carried out using $1 \mathrm{ml}$. of distilled water instead of the sugar solution. The absorbance of yellow- orange color was measured using spectrophotometer at wavelength $490 \mathrm{~nm}$. A standard curve was prepared using known concentrations of glucose. The established curve was used to convert the colorimeter absorbance into milligrams of glucose.

\section{2-5: Determination of crude protein:-}

Total nitrogen ( TN ) was determined (on dry weight basis) according to the modified micro-Kjeldahl method as described by the Association of Official Analytical Chemists, (AOAC, 2000). The crude protein contents were calculated using the conversion factor 6.25 .

$$
\text { Protein } \%=6.25(\mathrm{TN})
$$

\section{2-6: Extraction and determination of crude lipid:-}

A known weight of samples $(10 \mathrm{~g})$ was extracted with n-hexane for 6 hours, in Soxhlet apparatus. The solvent was evaporated and the residue was dried to a constant weight and the percentage of total lipid was calculated, according to AOAC, (2000).

\section{2-7: Determination of amino acids :-}

Amino acids were determined by A.O.A.C, (2012), performic oxidation methods :

Sample equal to $(10 \mathrm{mg})$ of protien was weighed in a conical flask and $5.0 \mathrm{ml}$. of performic acid was added, the flask was closed and placed in ice bath for $16.0 \mathrm{~h}, 5$ $\mathrm{ml}$ sodium disulfite and $25 \mathrm{ml} \mathrm{HCl} 6.0 \mathrm{~N}$ were added to the oxidized mixture, the flask was placed in an oven at $110 \mathrm{C}$ for 24 $\mathrm{h}$, the flask was then opened using rotary evaporator to reduce the volume to $5-10 \mathrm{ml}$ under vacuum at $60{ }^{\circ} \mathrm{C}$. Adjust the $\mathrm{pH}$ to 2.20 with soudium hydroxide solution. Suitable volume of sodium citrate buffer $(\mathrm{pH}$ 2.20) was added to hydrolyse sample. After all soluble material were completely dissolved, the sample was ready for analysis. The system used for the analysis were tested using a Biochrom 30 amino acid analyzer (Biochrom Ltd., Cambridge, UK) according to manufacturer's instructions and using validated clinical protocols, including deproteinization with sulfosalicylic acid and quantitation using S-2-aminoethylcystine as internal standard. Reaction temperature between $20^{\circ} \mathrm{C}$ and $40^{\circ} \mathrm{C}$ and there are 3 injection modes full loop, partial loop and micro autosampler and we use $200 \mu \mathrm{L}$ volumes of samples loop supplied as standard.

\section{2-8: Determination of phenolic compounds:-}

The amount of total phenolics in extracts was determined with the Folin- Ciocalteu reagent. Gallic acid was used as a standard and the total phenolics were expressed as mg gallic acid equivalents (GAE)/g dry weigh. $10 \mathrm{~mL}$ of samples were extracted in methanol. $0.5 \mathrm{~mL}$ of each sample and standard were introduced into test tubes and mixed with $2.5 \mathrm{~mL}$ of a 10 fold dilute FolinCiocalteu reagent and $2 \mathrm{~mL}$ of $7.5 \%$ sodium carbonate. The tubes were covered tightly and allowed to stand for 30 minutes at room temperature before the absorbance which was read at $760 \mathrm{~nm}$ spectrometrically.( Kim et al., 2003 ) .

\section{2-9: Determination of total flavonoids compounds:-}

The total flavonoids were determined using the method reported by Dewanto et 
al., (2002). Briefly, an aliquot of $250 \mu \mathrm{L}$ of each extract or a standard solution was mixed with $1.25 \mathrm{~mL}$ of deionised water followed by $75 \mu \mathrm{L}$ of a $5 \% \mathrm{NaNO}_{2}$ solution. After $6 \mathrm{~min}, 150 \mu \mathrm{L}$ of $10 \% \mathrm{AlCl}_{3} \cdot 6 \mathrm{H}_{2} \mathrm{O}$ solution was added to each mixture. After 5 min, $0.5 \mathrm{~mL}$ of $1 \mathrm{M} \mathrm{NaOH}$ was added, and the total volume was adjusted to $3.0 \mathrm{~mL}$ with deionised water. Catechin was used as a standard using absorbance at $510 \mathrm{~nm}$, which was corrected using a blank, the results were expressed as $\mathrm{mg}$ of catechin equivalents (CE)/ $g$ dry weight.

\section{2-10: Fractionation and quantitative determination of phenolic compounds by HPLC.}

Phenolic compounds were fractionated and determined by HPLC according to the method of Goupy et al., (1999) as follow : 5 $\mathrm{g}$ of samples were extracted by methanol and centrifuged at $10000 \mathrm{rpm}$ for $10 \mathrm{~min}$ and supernatant was filtered through a $0.2 \mu \mathrm{m}$ millipore membrane filter then 1-3 $\mathrm{ml}$ was collected in a vial and we use $200 \mu \mathrm{l}$ for injection in HPLC Hewilet Packared (series 1050 ) equipped with autosamplling injection , solvent degasser, ultravilot ( UV) detector set at $280 \mathrm{~nm}$ and quaternary HP pump (series 1050). Hewlett Packard using a column Altima C18, $5 \mathrm{~mm}(150 \mathrm{~mm} \times 4.6 \mathrm{~mm}$ Altech). The column temperature was maintained at $35{ }^{\circ} \mathrm{C}$. Gradient separation was carried out with methanol and acetonitrile as a mobile phase at flow rate of $1 \mathrm{ml} / \mathrm{min}$. Phenolic acid standards from sigma Co. were dissolved in a mobile phase and injected into HPLC. Retention time and peak area were used to calculate phenolic compounds concentration by the data of Hewllet Packared software. The data were reported with convergence limit in triplicate.

\section{2-11: Fractionation and quantitative determination of flavonoids by HPLC.}

HPLC analyses were performed with Dionex Ultimate 3000 liquid chromatograph (Germany) with four solvents delivery system quaternary pump (LPG 3400 SD) including a diode array detector (DAD 3000) with $5 \mathrm{~cm}$ flow cell, a manual sample injection valve equipped with a $20 \mu$ loop and Chromeleon 6.8 system manager as data processor. The separation was achieved by a reversed-phase acclaim TM $120 \mathrm{C} 18$ column $(5 \mu \mathrm{m}$ particle size, $4.6 \mathrm{x}$ $250 \mathrm{~mm}$ ). A modified method of Zuo et al. (2002) was used where the mobile phase contains $1 \%$ aq. acetic acid solution (Solvent A) and acetonitrile (Solvent B), the flow rate was adjusted to $0.7 \mathrm{ml} / \mathrm{min}$, the column was thermostatically controlled at $28{ }^{\circ} \mathrm{C}$ and the injection volume was kept at $20 \mu \mathrm{l}$. A gradient elution was performed by varying the proportion of solvent $B$ to solvent $A$. The gradient elution was changed from $10 \%$ to $40 \% \mathrm{~B}$ in a linear fashion for duration of 28 $\mathrm{min}$, from 40 to $60 \% \mathrm{~B}$ in $39 \mathrm{~min}$ and from 60 to $90 \%$ B in 50 min. The mobile phase composition comes back to initial condition (solvent B: solvent A: 10: 90) in $55 \mathrm{~min}$ and allowed to run for another $10 \mathrm{~min}$, before the injection of another sample.Total analysis time per sample was 65 min. HPLC chromatograms were detected using a photo diode array UV detector at three different wavelengths $(272,280$ and $310 \mathrm{~nm})$ according to absorption maxima of analysed compounds. Each compound was identified by its retention time and by spiking with standards under the same conditions. The quantification of the sample was done by the measurement of the integrated peak area and the content was calculated using the calibration curve by plotting peak area against concentration of the respective standard sample. The data were reported with convergence limit in triplicate.

\section{RESULTS AND DISCUSSION.}

\section{1: Chemical composition contents of} celery leaves and broccoli flowers:

The obtained results in Table (1) indicate that celery leaves contain moisture $88.72 \%$ fresh weight but total carbohydrates $36.8 \%$, crude protein $19.47 \%$, total lipids $2.18 \%$, crude fiber $19.85 \%$.and total ash $20.98 \%$ in dry weight. Our results are in line with those of Leung et al., (1968), Souci et al., 
(2000), Syed and Rajeev, (2012), Amnah and Alsuhaibani, (2013a) and Al Jawfi et al., (2013), they found that celery leaves and stalks contained moisture $80.30-93.5 \%$, crude protein $12-19.1 \%$, total lipid 1.6 $3.14 \%$, crude fibers $14-20 \%$, total carbohydrates $35-39 \%$ and total ash 14.2 $-19.9 \%$ respectively.

While broccoli flowers contained moisture $89.43 \%$ fresh weight but total carbohydrates $44.8 \%$, crude protein $24.79 \%$, total lipids $5.8 \%$, crude fiber $15.29 \%$.and total ash $7.67 \%$ in dry weight. These results are in agreement with those of Kahlon et al., (2005), Borowski et al., (2008) and Awad et al., (2012), they showed that gross chemical composition contents of broccoli were as follow : total carbohydrate $41.0-51.2 \%$, crude protein $24.1-33.2 \%$, crude fiber $12.77-21.1 \%$, total lipids $4.38-5.97 \%$, total ash $7.11-10.3 \%$ ( on dry matter ) and moisture $88.32-91.4 \%$ (on fresh matter).

\section{2: Total phenolic compounds and total flavonoids of celery leaves and broccoli flowers .}

Data in Table (2) showed that total phenolic and total flavonoid compounds in broccoli flowers were higher than that in celery leaves, whereas total phenolics in broccoli flowers was $38.4 \mathrm{mg} / \mathrm{g}$ and total flavonoids was $22.5 \mathrm{mg} / \mathrm{g}$. These results are in the same line with those obtained by Grover et al., (2002) and Amnah and Alsuhaibani, (2013 b) they found that total phenolics and flavonoids were 37.38 and $19.96 \mathrm{mg} / \mathrm{g}$ respectively. While the values were $30.3 \mathrm{mg} / \mathrm{g}$ and $18.5 \mathrm{mg} / \mathrm{g}$ total phenolics and total flavonoids respectively in celery leaves. These data are in agreement with those obtained by Elliot, (1999) and Jung et al., (2011) which showed that phytochemical contents in celery were 28.17 - $34.6 \mathrm{mg} / \mathrm{g}$ for total phenolics and 16.4 $19.6 \mathrm{mg} / \mathrm{g}$ for flavonoids.

\section{3: Amino acid analysis of celery leaves and broccoli flowers :}

Data presented in Table (3) showed that non essential amino acids of celery leaves were aspartic acid was detected as the major amino acid which recorded $23.37 \%$ followed by glycine, and serine $4.22 \%, 3.03$ $\%$ respectively while glutamic acid and alanine recorded $15.47 \%, 5.84 \%$ respectively . But for essential amino acids valine was the major amino acid which recorded $7.09 \%$ followed by leucine, phenylalanine, isoleucine, lysine, threonine and methionine which recorded $5.62 \%$, $5.52 \%, 4.11 \%, 4.11 \%, 3.62 \%$ and $1.3 \%$ respectively . For semi-essential, amino acids tyrosine, proline, arginine, cysteine and histidine recorded $4.22 \%, 4.0 \%, 3.78$ $\%, 2.49 \%$ and $2.16 \%$ respectively. These results are in the same line with those obtained by Ballmer et al., (2000) who showed that celery leaves contained amino acids such as arginine $3.75 \%$, histidine $2.25 \%$, isoleucine $4.20 \%$, leucine $5.52 \%$ , lysine $4.5 \%$, methionine $1.8 \%$, phenylalanine $5.43 \%$, threonine $3.55 \%$, tyrosine $4.31 \%$, valine $7.20 \%$, aspartic acid $23.62 \%$, alanine $5.74 \%$, glutamic acid $13.97 \%$, glycine $5.83 \%$, proline 6.67 $\%$, serine $1.66 \%$.

Table (1): Chemical composition of celery leaves and broccoli flowers

\begin{tabular}{|l|c|c|l|}
\hline \multicolumn{1}{|c|}{ Plants } & Celery leaves \% & Broccoli flowers \% & \\
\hline Moisture & 88.72 & 89.43 & in wet sample \\
\hline Total Carbohydrate & 36.8 & 44.8 & \\
\hline Crude Protein & 19.47 & 24.79 & \\
\hline Total Lipids & 2.18 & 5.8 & \multirow{2}{*}{ in dry sample } \\
\hline Crude Fiber & 19.85 & 15.29 & \\
\hline Total Ash & 20.98 & 7.67 & \\
\hline
\end{tabular}


Ashoush, et al.,

Table (2): Total phenolic compounds and total flavonoids content of celery leaves and broccoli flowers ( $\mathrm{mg} / \mathrm{g}$ dry weight).

\begin{tabular}{|l|c|c|}
\hline \multicolumn{1}{|c|}{ Plants } & Total phenolics $(\mathrm{mg} / \mathrm{g})$ & Total flvonoids $(\mathrm{mg} / \mathrm{g})$ \\
\hline Celery leaves & 30.3 & 18.5 \\
\hline Broccoli flowers & 38.4 & 22.5 \\
\hline
\end{tabular}

Table (3): Amino acid analysis of celery leaves and broccoli flowers.

\begin{tabular}{|l|c|c|l|c|c|}
\hline \multicolumn{1}{|c|}{ Amino Acid } & $\begin{array}{c}\text { Celery } \\
\text { leaves } \\
\%\end{array}$ & $\begin{array}{c}\text { Broccoli } \\
\text { flowers } \\
\%\end{array}$ & \multicolumn{1}{|c|}{ Amino Acid } & $\begin{array}{c}\text { Celery } \\
\text { leaves } \\
\%\end{array}$ & $\begin{array}{c}\text { Broccoli } \\
\text { flowers } \\
\%\end{array}$ \\
\hline Aspartic acid (ASP) & 23.37 & 11.05 & Isoleucine (ILE) & 4.11 & 3.84 \\
\hline Threonine (THE) & 3.67 & 3.56 & Leucine (LEU) & 5.62 & 5.81 \\
\hline Serine (SER) & 3.03 & 4.26 & Tyrosine (TYR) & 4.22 & 3.23 \\
\hline Glutamic acid (GLU) & 15.47 & 22.25 & Phenylalanine(PHE) & 5.52 & 4.82 \\
\hline Proline (PRO) & 4.0 & 5.81 & Histidine (HIS) & 2.16 & 2.39 \\
\hline Glycine (GLY) & 4.22 & 4.21 & Lysine (LYS) & 4.11 & 5.06 \\
\hline Alanine (ALA) & 5.84 & 8.01 & Arginine (ARG) & 3.78 & 6.89 \\
\hline Valine (VAL) & 7.09 & 6.56 & Cystine (CYS) & 2.49 & 1.08 \\
\hline Methionine & 1.3 & 1.17 & ------------------ & ------ & ----- \\
\hline
\end{tabular}

The amino acids composition of broccoli flowers are tabulated in Table (3). From the data in such table, it could be seen that non essential amino acids were glutamic acid was the major amino acids which recorded $22.25 \%$ followed by aspartic acid, alanine, serine and glycine which were $11.05 \%$, $8.01 \%, 4.26 \%$ and $4.21 \%$ respectively. As for essential amino acids, valine was the major amino acids which recorded $6.56 \%$ followed by leucine, lysine, phenylalanine, isoleucine, threonine and methionine which recorded $5.81 \%, 5.06 \%, 4.82 \%, 3.84 \%$, $3.56 \%$ and $1.17 \%$ respectively. For semiessential amino acids arginine, proline, tyrosine, cysteine and histidine recorded $6.89 \%, 5.81 \%, 3.23 \%, 2.39 \%$ and 1.08
$\%$ respectively. These data are in agreement with those obtained by $\mathrm{Hu}$ et al., (2011) who found that broccoli amino acid content was as follows methionine $1.35 \%$, lysine $5.32 \%$, cystine $1.2 \%$, threonine 3.28 $\%$, leucine $5.7 \%$, isoleucine $3.98 \%$, arginine $6.25 \%$, histidine $3.41 \%$, phenylalanine $4.95 \%$, valine $7.19 \%$, aspartic acid $10.35 \%$, glutamic acid $20.9 \%$ , alanine $9.04 \%$, proline $6.3 \%$, glycine $5.74 \%$ and tyrosine $5.04 \%$.

From data in such table it has been found the amino acids of high amounts in celery leaves were aspartic acid, glutamic acid and valine, while that of high values in broccoli flowers were glutamic acid, aspartic acid, 
alanine, arginine and valine. On the other hand, the other amino acids recorded results of convergent average.

\section{4: Quantitative analysis of phenolic compounds in celery leaves and broccoli flowers by HPLC.}

Phenolic compounds in celery leaves and broccoli flowers were analyzed by High Performance Liquid Chromatography (HPLC), and the concentrations of all tested phenolic compounds were given in Table (4).

From this table it was found that celery leaves contained pyrogallol as the main phenolic compound which reached 1037.74 ppm and showed high level of e-vanillic , ellagic, benzoic, chlorogenic, ferulic acid, $\mathrm{P}-\mathrm{OH}$-benzoic acid as well as caffeine which recorded $612.62,392.63,267.34,218.79$, $163.19, \quad 125.78$ and 100.61 ppm respectively.

Table (4): Quantitative analysis of phenolic compounds in celery leaves and broccoli flowers by HPLC.

\begin{tabular}{|l|c|c|}
\hline \multicolumn{1}{|c|}{ Phenolic compounds ( ppm ) } & Celery leaves & Broccoli flowers \\
\hline Pyrogallol & 1037.74 & 2898.52 \\
\hline Gallic acid & 16.51 & 2.10 \\
\hline 4-Amino-benzoic acid & 18.87 & 38.14 \\
\hline Protocatchuic acid & 43.17 & 83.79 \\
\hline Catechin & 48.24 & 78.51 \\
\hline Catechol & 20.55 & 28.61 \\
\hline Chlorogenic acid & 218.79 & 150.79 \\
\hline Epicatechin & 44.16 & 72.03 \\
\hline P-OH-benzoic acid & 125.78 & 183.04 \\
\hline Caffeine & 100.61 & 57.74 \\
\hline Caffeic acid & 36.57 & 21.28 \\
\hline Vanillic acid & 26.28 & 12.03 \\
\hline P-coumaric acid & 16.62 & 18.02 \\
\hline Ferulic acid & 163.19 & 55.11 \\
\hline Iso-ferulic acid & 27.87 & 0.33 \\
\hline E-vanillic acid & 612.62 & 161.95 \\
\hline Ellagic acid & 392.63 & 45.34 \\
\hline Alpha-coumaric acid & 18.44 & 1.89 \\
\hline Benzoic acid & 267.34 & 270.76 \\
\hline Coumarin & 49.37 & 1.13 \\
\hline 3,4,5 tri-methoxy-cinnamic acid & 24.25 & 29.34 \\
\hline Salycilic acid & ----- & 161.97 \\
\hline Cinnamic acid & 3.68 & 3.76 \\
\hline & & \\
\hline & & \\
\hline & & \\
\hline & & \\
\hline
\end{tabular}


Ashoush, et al.,

These results are in agreement with those of Erkan , (2012) who found that phenolic compounds of celery were as follow : protocateachuic acid $43.07 \mathrm{ppm}$, catechol $18.69 \mathrm{ppm}, \mathrm{P}$ - coumaric acid 17.07 ppm, catechin $49.28 \mathrm{ppm}$, caffeic acid $34.05 \mathrm{ppm}$, vanillic acid $603.43 \mathrm{ppm}$, pyrogallol 1012.34 ppm, ferulic acid 172.87 ppm and gallic acid 18.43 ppm.

Analysis of phenolic compounds in broccoli flowers showed that pyrogallol reached $2898.52 \mathrm{ppm}$, followed by benzoic acid , P-OH-benzoic acid, salycilic acid, evanillic acid and chlorogenic acid which were $270.76,183.04,161.97,161.95$ and 150.79 ppm respectively.

Results of phenolic compounds analysis are nearly similar to those reported by
Figueiredo et al., (2015) who found that phenolics compound contents were as follow: cinnamic $4.5 \mathrm{ppm}$, benzoic acid 265.8 ppm , pyrogallol 2845.2 ppm , ellagic acid $50.8 \mathrm{ppm}$, gallic acid $4.2 \mathrm{ppm}$, chlorogenic acid 139.9 ppm , caffeine 61.3 ppm and salycilic acid 158.4 ppm.

\section{5: Quantitative analysis of flavonoids in celery leaves and broccoli flowers by HPLC.}

Flavonoids in celery leaves and broccoli flowers were analyzed by High Performance Liquid Chromatography (HPLC), and concentrations of all tested flavonoids are given in Table (5).

Table (5): Quantitative analysis of flavonoids in celery leaves and broccoli flowers by HPLC.

\begin{tabular}{|l|c|c|}
\hline \multicolumn{1}{|c|}{ Flavonoids (mg/100g) } & Celery leaves & Broccoli flowers \\
\hline Luteo. 6-arbinose 8-glucose & 93.19 & 114.59 \\
\hline Luteo. 6-glucose 8-arbinose & 5.48 & 6.55 \\
\hline Apig. 6-rhamnose 8-glucose & 124.24 & 4.67 \\
\hline Apig. 6-glucose 8-rhamnose & 13.03 & 8.79 \\
\hline Naringin & ----- & 16.84 \\
\hline Luteolin & 134.63 & 35.93 \\
\hline Hesperidin & 103.94 & 87.91 \\
\hline Rutin & 13.39 & 2.54 \\
\hline Quercetrin-3-o-glucoside & ---- & 3.37 \\
\hline Rosmarinic acid & 997.03 & 50.93 \\
\hline Apig.7-O-neohespiroside & 6.07 & ---- \\
\hline Kaemp.3,7-dirhamoside & 19.12 & 6.86 \\
\hline Apig. 7-glucose & 9.54 & 1.17 \\
\hline Quercetrin & 13.89 & 7.69 \\
\hline Quercetin & ---- & 1.63 \\
\hline Kaem.3,(2-p-comaroyl) glucose & ---- & 11.21 \\
\hline Naringenin & ---- & 3.85 \\
\hline Hesperetin & 9.42 & 5.85 \\
\hline Kaempferol & 1.73 & 0.38 \\
\hline Rhamnetin & 1.25 & 0.96 \\
\hline Apigenin & 0.84 & 0.51 \\
\hline Acacetin & 102.04 & 19.67 \\
\hline & & \\
\hline
\end{tabular}


From this table, it was found that celery leaves contained rosmarinic as the main flavonoid which reached $997 \mathrm{mg} / 100 \mathrm{~g}$ with high level of luteolin , apig.6-rhamnose 8glucose, hesperidin, acacetin and luteo.6arbinose 8-glucose which were amounted of $134.63,124.24,103.94,102.04$ and 93.19 $\mathrm{mg} / 100 \mathrm{~g}$ respectively and low level of apig.7-glucose, hesperetin , apig.7-Oneohespiroside, kaempferol, rhamnetin and apigenin which had values of 9.54, 9.42, $6.07,1.73, \quad 1.25$ and $0.84 \mathrm{mg} / 100 \mathrm{~g}$ respectively.

Results of flavonoids analysis are nearly similar to those reported by Benhammou et al., (2007) who studied the main flavonoids of celery leaves and found that celery leaves contained kaempferol $2.1 \mathrm{mg}$, luteolin 132.9 $\mathrm{mg}$, rutin $15.3 \mathrm{mg}$, rosmarinic $964.7 \mathrm{mg}$, apigenin $1.92 \mathrm{mg}$, hesperidin $110.1 \mathrm{mg}$, acacetin $100.4 \mathrm{mg}$ and rhamnetin 2.3 $\mathrm{mg} / 100 \mathrm{~g}$.

Analysis of flavonoids in broccoli flowers showed that the main flavonoid was luteo.6arbinose 8-glucose reached 114.59 $\mathrm{mg} / 100 \mathrm{~g}$ as well as high level of hesperidin , rosmarinic and luteolin which were 87.91, 50.93 and $35.93 \mathrm{mg} / 100 \mathrm{~g}$ respectively, followed by acacetin , naringin, hesperetin, naringenin, rhamnetin, kaempferol and apigenin which were $19.67,16.84,5.85$, $3.85,0.96,0.38$ and $0.51 \mathrm{mg} / 100 \mathrm{~g}$ respectively.

These results is agreed also with those of Galan et al., (2004) who indicated that flavonoids found in broccoli flowers were naringin $18.3 \mathrm{mg}$, apigenin $1.8 \mathrm{mg}$, luteo.6arbinose 8-glucose $112.8 \mathrm{mg}$, hesperidin $91.9 \mathrm{mg}$, rosmarinic acid $49.2 \mathrm{mg}$, luteolin $38.7 \mathrm{mg}$ and quercetrin $9.3 \mathrm{mg} / 100 \mathrm{~g}$.

\section{Conclusion.}

Celery leaves contained 17 amino acids as among them there were essential amino acids as valine, leucine and isoleucine and non essential amino acids as aspartic acid, glycine and serine as well as semi-essential amino acids as arginine, proline and histidine. Broccoli flowers contained 17 amino acids. Essential amino acids were valine, lysine and methionine. Non essential amino acids were glutamic acid, aspartic acid and alanine. While semi-essential amino acids were cysteine, arginine and proline. Celery leaves were found to contain 22 of phenolic compounds, among them pyrogallol, e.vanillic acid, ellagic acid, benzoic acid, chlorogenic acid, ferulic acid and caffeine were the major active constituents comparing with 23 of phenolic compounds in broccoli flowers which contained pyrogallol, benzoic acid, chlorogenic acid, and salycilic acid those were the major of constituents phenolic compounds. Celery leaves contained 17 of flavonoids, the highest values of them were rosmarinic, luteolin, hesperidin and apig.6rhamnose 8-glucose comparing with 21 of flavonoids in broccoli flowers from which the highest amounts were of luteo.6-arbinose 8glucose, hesperidin and rosmarinic. Broccoli flowers showed high contents of total phenolic compounds and flavonoids comparing with celery leaves.

\section{REFERENCES}

Abou El-Magd, M.M., A.M. El-Bassiony and Z.F. Fawzy (2006). Effect of organic manure with or without chemical fertilizers on growth, yield and quality of some varieties of broccoli plants. J. App. Sci. Res. 2:791-798.

Al Jawfi, Y., M. Alsayadi, A. Benmansour, S. D. Chabane and H. A. Lazoni (2013). Chemical and Phytochemical Analysis of Some Antidiabetic Plants in Yemen. Al Jawfi Yaser et al. Int. Res. J. Pharm. 4 (9): 28-32.

Amnah, M. and A. Alsuhaibani (2013 a). Antioxidant activity of celery in vitro and in vivo. J. Am. Sci. 9 (6): 15-20.

Amnah, M. and A. Alsuhaibani (2013 b). Effect of Broccoli on the Antioxidant Activity of Experimental Rats Ingested 
Thermally Oxidized Oil. Nat. Sci.11 (12):1-7.

Antuono, L. F., R. Neri and A. Moretti (2002). By-products of vegetable celery (Apium graveolens L. var. Dulce) as potential source of flavours. Acta Horticulturae., 57 (6): 327-333.

Association of Official Analytical Chemists AOAC. (2000).Official Methods of Analysis, 15th Edn. AOAC, Washington, D.C.

Association of Official Analytical Chemists AOAC. (2012). Official $17^{\text {th }}$ edn.Washington Dc.,U.S.A.

Awad, R.A., Azza M. Farahat_and Wafaa_M. Salama (2012): Production and in vivo Nutritional Evaluation of Functional Soft Cheese Supplemented with Broccoli. World J. Dairy and Food Sci. 7 (2): 150159.

Ballmer, W., M. Besler, S. Hoffmann, S. Vieths and W. Brunello (2000). The present data collection reviews detailed information on the prevalence and symptoms of celery allergy as well as cross- reactivities, and molecular biological and allergenic properties of the major celery allergens in tabular form. Internet Symposium on Food Allergens .2(3):145-167.

Benhammou, N., F. Atik, M. Bekkara and P.T. Kadifkova (2007). Antiradical capacity of the phenolic and flavonoid compounds of celery and parley. Food chem. 1: $247-254$.

Borowski, J., A. Szajdek and E.J. Borowska (2008). Content of selected bioactive components and antioxidant properties of broccoli (Brassica oleracea L.). Eur. Food Res. Technol. 246, 459-465.

Dewanto, V., X. Wu, K.K. Adom and R.H. Liu (2002). Thermal processing enhances the nutritional value of tomatoes by increasing total antioxidant activity. J. Agric. Food Chem. 50: 30103014.

Dubois, M., F. Smith, K.A. Gilles, J.K. Hammilton and P.A. Rebers (1956). Colorimetric method for determination of sugars and related substance. Anal.Chem. 28 (3): 350 - 356 .

Elliot, JG (1999). Application of antioxidant vitamins in foods and beverages. Food Technol. 53: 46-48.

Erkan, N. (2012). Antioxidant activity and phenolic compounds of fractions from Portulaca oleracea L. Food Chem. 133: 775-781.

Figueiredo, S.M., N.S. Binda, J.A. NogueiraMachado, S.A. Vieira-Filho and R.B. Caligiorne (2015). The antioxidant properties of organosulfur compounds (Sulforaphane). Recent. Pat. Endocr. Metab. Immune. Drug Discov. 9: 24-39.

Galan, M.V., A.A. Kishan and A.L. Silverman (2004). Oral broccoli sprouts for the treatment of Helicobacter pylori infection: a preliminary report. Dis. Dig. Sci. 49:1088-1090.

Goupy, P., M. Hugues, P. Biovin and M.J. Amiot (1999). Antioxidant composition and activity of barley (Hordeum Vuigare) and malt extracts and of isolated phenolic compounds. J. Sci. Food Agric. 79: 1625 $-1634$.

Grover, JK., S. Yadav and V. Vats (2002). Medicinal plants of India with antidiabetic potential. J. Ethnopharmacol. 81: 81-100.

Halim, A.F., M. M. Mashaly, O. Salama, A.F. Ali and P. Sandra (1990). Analysis of celery fruit oil and investigation of the effect of storage. Egypt. J. Pharm. Sci. 31 (1- 4): 107-113.

Hu, C. H., A. Y. Zuo, D. G. Wang, H. Y. Pan, W. B. Zheng, Z. C. Qian and X. T. Zou. (2011). Effects of broccoli stems and leaves meal on production performance and egg quality of laying hens. Anim. Feed Sci. Technol. 170:117-121.

Jung, W. S., I. M. Chung, S. H. Kim, M. Y. Kim, A. Ahmad and N. Praveen (2011). In vitro antioxidant activity, total phenolics and flavonoids from celery (Apium graveolens) leaves. J. Med. Plants Res. 5(32): 7022-7030.

Kahlon, T.S., M.H. Chapman and G.E. Smith (2005). In vitro binding of bile acids 
by spinach, kale, brussels sprouts, broccoli, mustard greens, green bell pepper, cabbage and collards. Food Chem. 100: 1531-1536.

Kim, D.O., S.W. Jeong and C.Y. Lee (2003). Antioxidant capacity of phenolic phytochemicals from various cultivars of plums. Food Chem. 81:321-326.

Leung, W., F. Busson and J. Cardin (1968). Food composition table for use in Africa. FAO, Rome, Italy. pp 306.

Price, K.R., F. Casuscelli, I.J. Colquhoun and G. Williamson (1998). Composition and content of flavonol glycosides in broccoli flowers (Brassica olearacea) and their fate during cooking. J. Sci. Food Agric. 77: $468-472$.

Souci, S.W., W. Fachmann and H. Kraut (2000). Food composition and nutrition tables 6th edn. (eds) Deutsche Forschungsanstalt

f"ur
Lebensmittelchemie, Garching b. M"unchen, Medpharm Scientific Publishing, Stuttgart, Germany (Boca Raton, London, NewYork,Washington, DC:CRCPress) pp 681- 682.

Syed S.F. and Rajeev K.S. (2012) : Review on the Pharmacognostical and Pharmacological Characterization of Apium Graveolens Linn. Indo Global J. Pharmaceut. Sci. 2(1): 36-42.

Yoldas, F., S. Ceylan, B. Yagmur and N. Mordogan (2008). Effect of nitrogen fertilizer on yield quality and nutrient content in broccoli. J. Plant Nut. 31: 1333 -1343 .

Zuo, Y., H. Chen and Y. Deng (2002). Simultaneous Determination of Catechins, Caffeine and Gallic acids in Green, Oolong and Black tea using HPLC with a Photodiode Array Detector. Talanta, 57: 307-316. 
دراسة مقارنة بين أورلق الكرفس وأزهار البروكلى من حيث التركيب الكيميائي و الأحماض

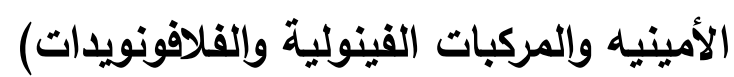

\author{
يوسف أمين محمد عشوش(1) ، أحمد محمد فريد على(1)، مدحت مصطفي أبوزيد(1) ،

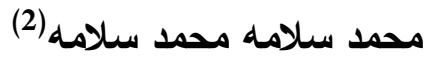

(1) قسم الكيمياء الحيوية الزراعيه - كلية الزراعة - جامعة المنوفية

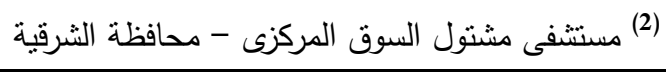
الملخص العربي

تمت دراسة التركيب الكيميائي لأوراق الكرفس وأزهار البروكلى ومكوناتها من الأحماض الأمينيه وكذلك المركبات الفينولية والفلافونويدات ويمكن تلخيص نتائج هذه الدراسه فيما يلى :أولا التركيب الكيميائى . أمبات 1-أولق الكرفس : تحتوى على 88,72\% رطوبه فى العينه الطازجه فى حين أن العينات الجافه تحتوى على

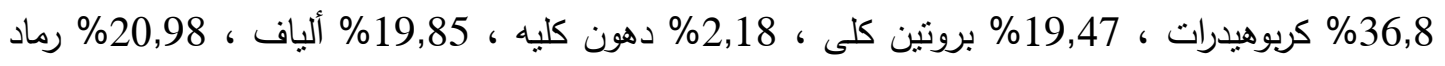
كلى كما يوجد بها 30.3 مجم|جم فينولات كليه ، 18,5 مجماجم فلافونويدات كلئ ، 2-أزهار البروكلى : تحتوى على 89,43\% رطوبه فى العينه الطازجه فى حين أن العينات الجافه تحتوى على بلى

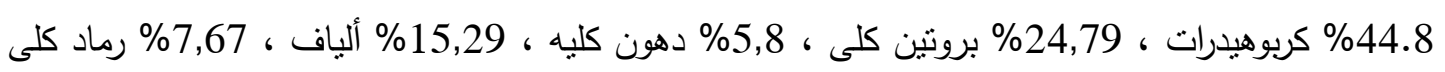
كما يوجد بها 38,4 مجم|جم فينولات كليه ،22,5مجم|جم فلافونويدات كليه.

ثانيا الأحماض الأمينيه . ثماضيه نم تقدير الأحماض الأمينيه عن طرق جهاز تفريد الأحماض الأمينيه (Amino acid analyser) وكانت النتائج كما يلى : 1- أولق الكرفس : تحتوى على 17 حمض أمينى وكانت كمية الأحماض الأمينيه الأساسيه منها 31,42\%

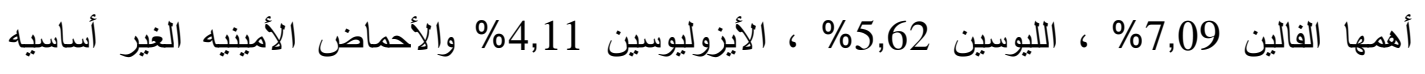

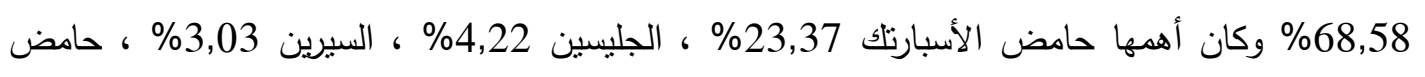

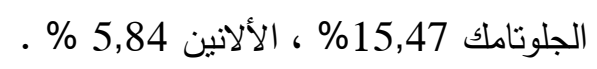

2- أزهار البروكلى : تحتوى على 17 حمض أمينى وكانت كمية الأحماض الأمينيه الأساسيه منها 30.82\%

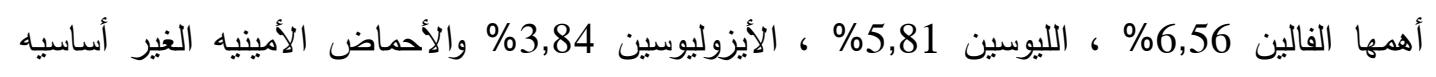

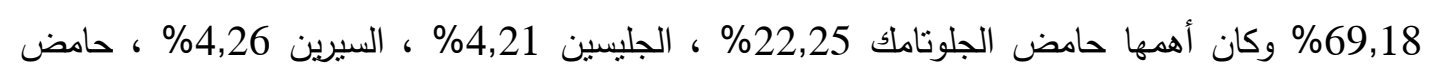

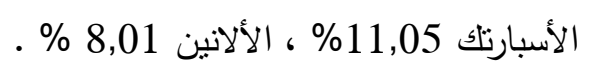

ثالثا تقدير الفلافونيدات . تم تقدير المركبات الفلافونويديه بواسطة جهاز (HPLC) والذى أظهر النتائج التاليه : 
1- أولق الكرفس : تحتوى على 17 مركب أهمها حامض الروسمارينيك 997,03 مجم|100جم ، اللونيولين

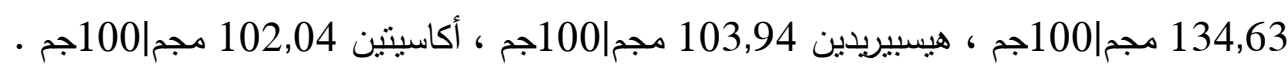

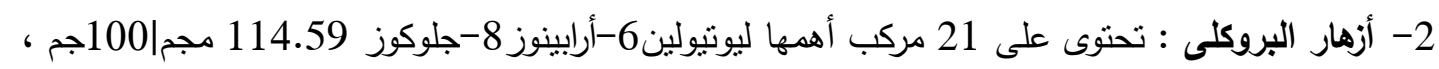

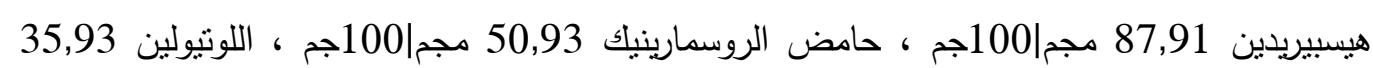

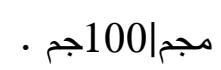

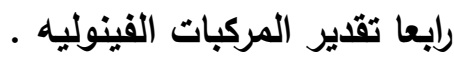

تم تقدير المركبات الفينوليه بواسطة جهاز (HPLC) والذى أظهر النتائج التاليه :

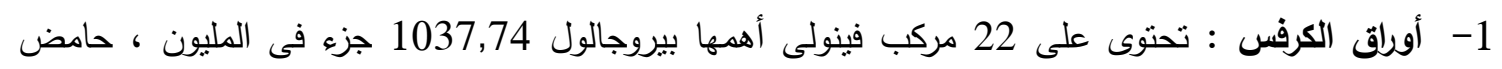

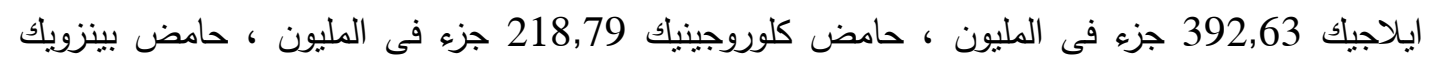

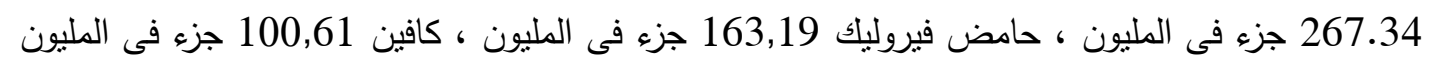
، كاتيشين 48,24 جزء فى المليون .

2- أزهار البروكلى : تحتوى على 23 مركب أهمها بيروجالول 2898,52 جزء فى المليون ، حامض بينزويك

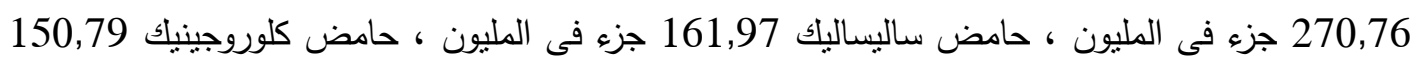

جزء فى المليون ، حامض برتوكاتثويك 83,79 جزء فى المليون ، كاتيشين 78,51 جزء في في المليون •

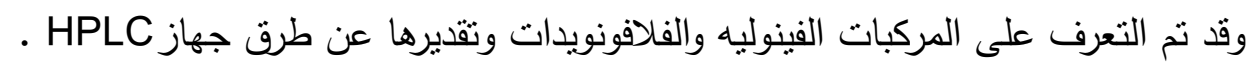

